\title{
Immunohistochemical assessment of HER2 expression in gastric cancer in a cohort of 118 Brazilian patients
}

\author{
Avaliação da expressão imuno-bistoquímica do HER2 em \\ câncer gástrico em uma coorte de 118 pacientes brasileiros
}

Juliana Elizabeth Jung'; Sérgio Ossamu Ioshii

\begin{abstract}
Introduction: Recent studies indicate a role of human epidermal growth factor receptor type 2 (HER2) in the development of numerous types of human cancer, including gastric cancer, and its overexpression correlates with poor prognosis and increased aggressiveness of this neoplasm. Objectives: Identify and evaluate the immunohistochemical expression of HER2 in gastric cancer from biopsies, surgical resection specimens, lymph node metastasis and distant metastasis, and evaluate their correlation with currently known clinical and histopathological prognostic factors. Methods: Samples from 118 patients of both sexes and all age groups diagnosed with gastric cancer were analyzed. Immunohistochemistry (IHQ) was performed using the HER2 antibody, and its evaluation was made according to the modified gastric cancer testing protocol, taking into account incomplete basolateral staining or only lateral staining. Results: HER2 expression did not correlate with any histological prognostic factors or clinical outcome, except for the $\mathrm{N}$ stage. By comparing the HER2 expression in biopsies, surgical specimen, lymph node and metastasis, $88.1 \%$ were in agreement. Conclusion: As anti-HER2 therapies are becoming the standard of care in gastric cancer, currently available data indicate that IHQ should be used as the screening test, and the pathologist has an important role to ensure an accurate testing of HER2 status in these tumors. In addition, the HER2 status can be tested using the available samples from biopsies, surgical specimens, nodal and extranodal metastatic disease.
\end{abstract}

Key words: HER2; immunohistochemistry; gastric cancer; tissue microarray; prognosis.

\section{INTRODUCTION}

The human epidermal growth factor receptor type 2 (HER2) oncogene is localized in chromosome 17 and encodes a transmembrane tyrosine kinase receptor that has evolved as a major classifier of invasive breast cancer and target of therapy for the disease ${ }^{(23)}$. HER2 signaling has been associated with a variety of downstream pathway activities and with a wide variety of cellular processes, including increased cell motility, invasiveness, angiogenesis, resistance to apoptosis and metastatic potential ${ }^{(23)}$. HER2 gene amplification and/or protein overexpression has been identified in $10 \%-34 \%$ of invasive breast cancers, being associated with increased cell proliferation, cell motility, tumor invasiveness, progressive regional and distant metastases, accelerated angiogenesis, and reduced apoptosis ${ }^{(20)}$.

Recent studies indicate a role of HER2 in the development of numerous types of human cancer, including gastric cancer ${ }^{(4)}$, and its overexpression has been correlated to poor outcome and more aggressive disease ${ }^{(17,27)}$.

Gastric cancer is one of the most common tumors, and the most recent global estimates indicated the occurrence of about one million new cases of stomach cancer for the year 2008, setting it as the fourth most common cause of $\operatorname{cancer}^{(7,10)}$. Over $70 \%$ of cases

First submission on 16/01/13; last submission on 02/08/13; accepted for publication on 05/08/13; published on 20/10/13

1. Doctorate in Clinical Surgery from Universidade Federal do Paraná (UFPR); pathologist at Hospital Erasto Gaertner:

2. Doctorate in Pathology from Mie University, Japan; associate professor at UFPR and Pontifícia Universidade Católica do Paraná (PUC-PR); pathologist at Hospital Erasto

Gaertner. 
occur in developing countries ${ }^{(10)}$. In addition, the incidence rate is about twice as high in males than in females ${ }^{(7)}$. In 2012, for Brazil, 12,670 new cases of gastric cancer in men and 7,420 new cases in women were estimated. These values correspond to an estimated risk of 13 new cases per 100,000 men and seven new cases per 100,000 women $^{(7)}$

The objective of the present study was to identify and evaluate the immunohistochemical expression of HER2 in gastric cancer from biopsies, surgical resection specimens, perigastric lymph node metastasis and distant metastasis, and to evaluate their correlation with currently known clinical and histopathological prognostic factors. We hypothesize that the correlation of clinical and histopathological findings with HER2 immunohistochemical expression may enable identification of biological markers and proteins involved in the pathogenesis, development, and progression of gastric cancer, with possible implications for prognosis and treatment of the disease.

\section{METHODS}

\section{Gastric cancer specimens}

This study was based on formalin-fixed and paraffinembedded surgical specimens from 118 patients of both sexes and all age groups who were diagnosed with gastric cancer between 2005 and 2009 in the Surgical Oncology Unit at Hospital Erasto Gaertner, Curitiba, Paraná, Brazil.

The following clinical variables were tabulated: age, sex and clinical outcome - death from gastric cancer and presence of distant metastasis.

The histopathological variables were the depth of invasion of the gastric wall (T) and the involvement of perigastric lymph nodes (N), based on the Protocol for the Examination of Specimens from Patients with Carcinoma of the Stomach - American Joint Committee on Cancer/International Union Against Cancer/ Classification of Malignant Tumours (AJCC/UICC/TNM) ${ }^{(26)}$. In order to simplify the statistical correlations, the primary tumor staging was divided into:

- pT1 - tumor invades lamina propria, muscularis mucosae, or submucosa;

- pT2 - tumor invades muscularis propria;

- pT3 - tumor invades subserosal connective tissue, without involvement of visceral peritoneum or adjacent structures;

- pT4 - tumor involves serosa (visceral peritoneum) or adjacent structures.
The cases where regional lymph nodes were available for analysis, the division was as follows:

- N0 - no regional lymph node metastasis;

- N1 - metastasis in 1 to 2 perigastric lymph nodes;

- $\mathrm{N} 2$ - metastasis in 3 to 6 perigastric lymph nodes;

- $\mathrm{N} 3$ - metastasis in 7 or more perigastric lymph nodes.

Metastatic disease was considered when involvement of other organs or lymph nodes - other than the perigastric - was histologically proved.

The tumor histologic type was classified, according to Lauren $^{(12)}$, as: intestinal, diffuse or mixed type.

Immunohistochemical analysis was carried out after histological slides had been prepared by the tissue microarray (TMA) technique, described by Kononen et $a l^{(11)}$ and adapted by Rocha $e t a l .{ }^{(18)}$, who just as in the present study, used an alternative and economic method. The TMAs were pre-selected with representative samples from tumor biopsies (one sample per patient), surgical resection specimens (two samples per patient), perigastric lymph node metastasis (one sample perpatient) and distantmetastasis (onesample perpatient), according to which one was available for each patient. When the patient had two or more specimens, all of them were included for analysis and posteriorly paired. For the construction of the tissue microarray, slides were analyzed and the original area of interest was selected. Then, the selected area was identified in the original paraffin blocks (donor blocks), and a tissue cylinder of $2 \mathrm{~mm}$ was removed from this area, using a metal tool known as a "punch" for skin biopsies. The cylinder was then inserted into a new block (receptor block), containing eight samples per block - divided into four rows and four columns. The position of each patient was identified in a spreadsheet. In the case of surgical resection specimens where two samples of each patient were included in the TMA, the higher obtained score was considered for the analysis.

Immunohistochemistry (IHQ) was performed with the HER2 antibody, clone CB 11 (Novocastra ${ }^{\mathrm{TM}}$, New Castle, UK), diluted $1: 1,600$, following the manufacturer's protocol $(\mathrm{pH} 6$, water bath at $95^{\circ} \mathrm{C}$ for 40 minutes). A 2-mm cylinder of a breast cancer HER2 $3+$ used as positive control was present in all TMA slides.

Evaluation was performed according to the modified gastric cancer testing protocol, taking incomplete basolateral or only lateral staining into account ${ }^{(6)}$. TMA cores were tested analogous to biopsies ${ }^{(())}$.

- score 0: no membrane reactivity in any tumor cell;

- score 1+: group of tumor cells with weak or incomplete membrane reactivity; independent of the percentage of stained cells; 
- score 2+: group of tumor cells with weak to moderate membrane reactivity, complete, basolateral or lateral staining; independent of the percentage of stained cells;

- score 3+: group of tumor cells with strong membrane reactivity, complete, basolateral or lateral staining; independent of percentage of stained cells (Figure).

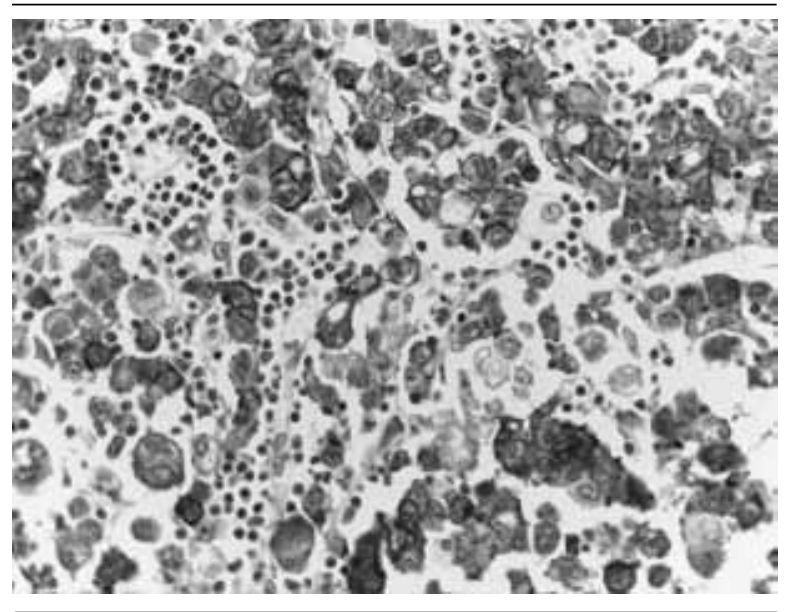

FIGURE - Diffuse-type gastric carcinoma HER2 3+ with signet-ring cells showing strong membrane staining $(20 \times)$

HER2: buman epidermal growth factor receptor-type 2.

The slides were independently reviewed by two pathologists, to confirm the diagnosis of gastric cancer and to score the expression of HER2.

Statistical analysis was carried out using the Proportion Test $(\phi$ value statistically significant difference, with $p=0.0000$ ) and the Spearman's Correlation Test ( $\phi$ value statistically significant difference, with $p<0.05$ ).

This study was approved by the ethics committee of Hospital Erasto Gaertner, Curitiba, Paraná, Brazil.

\section{RESULTS}

\section{Patient data}

Among the 118 patients included in this study, 75 were male (63\%) and 43 were female (36\%). The age ranged from 27 to 87 years. At the end of the study, 62 patients (52.5\%) died from causes directly related to gastric cancer, and 56 (47.5\%) were alive.

Metastatic disease was histologically proven in 36 (30.5\%) of all patients: peritoneum in 24 cases $(66.6 \%)$, supraclavicular lymph node in four cases (11.1\%), subcutaneous tissue of abdominal wall in three cases (8.3\%), liver in two cases (5.5\%), ovary in two cases (5.5\%), and pancreas in one case (2.7\%).

The 63 patients (53.4\%) submitted to surgical resection were divided according to the depth of invasion of the gastric wall (T) and the involvement of lymph nodes (N), as presented in Table $\mathbf{1}$.

\begin{tabular}{cccccc}
\hline \multicolumn{5}{c}{$\begin{array}{c}\text { TABLE 1 - Frequency and percentage of patients with } \\
\text { surgically resected gastric cancer divided according to } \\
\text { tumor size (T) and regional lymph nodes metastasis (N) }\end{array}$} \\
\hline Tumor size & Frequency & $\%$ & $\begin{array}{c}\text { Regional } \\
\text { lymph nodes }\end{array}$ & Frequency & $\%$ \\
\hline T1 & 10 & 8.5 & N0 & 25 & 21.2 \\
T2 & 8 & 6.8 & N1 & 10 & 8.5 \\
T3 & 18 & 15.3 & N2 & 15 & 12.7 \\
T4 & 27 & 22.9 & N3 & 13 & 11 \\
Total & 63 & 53.4 & Total & 63 & 53.4 \\
\hline
\end{tabular}

The predominant histologic type of gastric cancer in this study was the diffuse type: 92 cases (78\%), followed by the mixed type: 24 cases (20.3\%). Only two cases were classified as intestinal type (1.7\%).

\section{HER2 data}

\section{Frequency of HER2 expression}

The frequency of HER2 $2+$ and $3+$ in gastric cancer from biopsies, surgical resection specimens, perigastric lymph node metastasis and distant metastasis was $5.9 \%, 2.5 \%, 3.3 \%$, and $2.5 \%$, respectively. Table 2 shows the frequency of HER2 expression in the different analyzed samples.

TABLE 2 - Frequency of HER2 expression in biopsies, surgical resection specimens, perigastric lymph node metastasis and distant metastasis

\begin{tabular}{ccccccccc}
\hline & \multirow{2}{*}{ Biopsy } & \multicolumn{3}{c}{$\begin{array}{c}\text { Surgical resection } \\
\text { specimen }\end{array}$} & $\begin{array}{c}\text { Lymph } \\
\text { node }\end{array}$ & \multicolumn{2}{c}{$\begin{array}{c}\text { Distant } \\
\text { metastasis }\end{array}$} \\
\hline HER2 & Frequency & $\%$ & Frequency & $\%$ & Frequency & $\%$ & Frequency & $\%$ \\
\hline 0 & 10 & 8.5 & 36 & 30.5 & 19 & 16.1 & 24 & 20.3 \\
$1+$ & 19 & 16.1 & 24 & 20.3 & 6 & 5.1 & 9 & 7.6 \\
$2+$ & 5 & 4.2 & 2 & 1.7 & 1 & 0.8 & 5 & 1.7 \\
$3+$ & 2 & 1.7 & 1 & 0.8 & 3 & 2.5 & 1 & 0.8 \\
Total & 36 & 30.5 & 63 & 53.4 & 29 & 24.6 & 36 & 30.5 \\
\hline
\end{tabular}

Thirty-eight patients (32\%) had two or more samples evaluated. In 24 patients (63.1\%), the expression of HER2 was the same in all samples. In ten patients $(26.3 \%)$, the expression of HER2 was different, and in four patients (10.5\%), the expression was the same in two samples, and different in one sample. When comparing the HER2 expression in biopsies, surgical specimen, 
lymph node and metastasis, there is no statistically significant difference $(\phi>0.05)$.

\section{Correlation of HER2 expression with clinical data}

Our data showed no statistically significant difference concerning the sex and age of the patients, and clinical outcome $(p>0.05)$.

\section{Correlation HER2 expression with histological parameters}

No association between HER2 expression with histological type, $\mathrm{T}$ stage and $\mathrm{M}$ stage could be identified $(p>0.05)$. There was only significant statistical correlation with the $\mathrm{N}$ stage $(\phi<0.05)$.

\section{DISCUSSION}

The standard treatment for gastric carcinoma is surgical resection, the extent of it being largely dependent on the extent of tumor and the status of the rest of the mucosa ${ }^{(6)}$. Surgery can cure patients with early-stage cancer, but in Western countries, most gastric cancer patients are diagnosed when the tumor is at an unresectable stage $e^{(4)}$. Despite improvements in surgical techniques and the use of multimodal treatment, the prognosis for gastric carcinoma remains disappointingly poor. The overall survival rates for patients in the United States are between $4 \%$ and $13 \%{ }^{(3,19)}$.

The investigation of molecular and genetic changes in gastric cancer has brought new insights into the pathogenesis of the disease ${ }^{(3)}$. For patients with unresectable disease, systemic chemotherapy is the main treatment option, because it prolongs survival, and a better understanding of the molecular basis of cancer has contributed to the development of rationally-designed molecular-targeted therapies, which interfere with the signaling cascades involved in cell differentiation, proliferation, and survival $^{(3,4)}$

HER2 overexpression is increasingly recognized as a frequent molecular abnormality, occurring in about $20 \%$ of cases $^{(4,29)}$. Overexpression of HER2 protein in gastric cancer using IHQ was first described in $1986^{(21)}$, however, in contrast to breast cancer, HER2 expression and amplification in gastric cancer is much more heterogeneous, and ring-shaped staining is more an exception than the rule ${ }^{(1)}$

In our study we evaluated the immunohistochemical expression of HER2 in gastric cancer from biopsies, surgical resection specimens, perigastric lymph node metastasis and distant metastasis, and the frequency of HER2 positivity (2+ and $3+$ ) was $5.9 \%, 2.5 \%, 3.3 \%$ and $2.5 \%$, respectively.

In the 1990s, some series reported a 9\%-38\% of HER2-positive tumors using polyclonal antibodies directed against different domains of HER2 protein and restricting the evaluation to the staining of the cell membrane ${ }^{(8,27,31)}$. In the Trastuzumab for Gastric Cancer (ToGA) trial, 3,280 of the 3,883 screened gastric/ gastro-esophageal junction (GEJ) cancers had successful HER2 testing by both IHC and fluorescence in situ hybridization (FISH). There were 2,857 HER2- results and 810 HER2+ cases for a HER2+ rate of $22.1 \%{ }^{(2)}$. Of the 756 cases that were FISH+, 94 (12\%) were IHC, $0.96(13 \%)$ were IHC $1+, 212$ (28\%) were IHC $2+$, and 354 (47\%) were IHC $3+{ }^{(1)}$.

One possible explanation for this lower positivity is that the majority of the tumors evaluated were of the diffuse type with signet ring cells $(78 \%)$. The mixed type constituted $20.3 \%$ of the sample, and the tubular type, only $1.7 \%$. Also, in the ToGA trial, the highest HER2+ rate was in the intestinal subtype of gastric carcinoma compared with the diffuse and mixed types (34\% intestinal, $6 \%$ diffuse, $20 \%$ mixed) ${ }^{(2)}$. Gravalos et al. observed a higher rate of HER2 overexpression in intestinal than in diffuse type (16\% versus $7 \%)^{(5)}$, and in the study by Park et al., intestinaltype cancers also exhibited higher rates of HER2 amplification than did diffuse-type cancers $(\phi<0.05)^{(17)}$.

At least three studies reported that HER2 expression is more common in GEJ cancers than in gastric tumors ${ }^{(5,14,25)}$. One study showed a $25 \%$ versus 9.5\% HER2 overexpression and/or amplification in GEJ and in gastric cancers, respectively $(p=0.01)^{(5)}$. Tanner et al. also found a higher rate of HER2 positivity in GEJ cancers than in gastric tumors (24\% versus $12 \%{ }^{(25)}$. These results have been confirmed in a large number of patients in the ToGA study, in which HER2 positivity was found in $32 \%$ and $18 \%$ in GEJ and gastric cancers, respectively ${ }^{(2)}$. We could not compare the expression of HER2 according to primary tumor site (gastric versus GEJ) due to lack of information either in the patients' chart regarding the location of the tumor when they were only submitted to biopsy or on the gross description of the surgical resection specimen.

In our study, HER2 expression by FISH or chromogenic in situ hybridization (CISH) was not performed. The concordance of protein expression and gene amplification of HER2 in gastric cancer, however, have been controversial, but recent studies report a high concordance between overexpression in IHC and amplification by FISH or CISH ${ }^{(4)}$. In the ToGA trial, the concordance between HER2 positivity by IHC and FISH was $87 \%{ }^{(2)}$. In a series of 40 cases analyzed by Lemoine et al., 26\% 
were found to display elevated protein expression, but only $13 \%$ evidenced gene amplification ${ }^{(13)}$. A similar result was obtained by Kameda et al., who detected overexpression without amplification and considered that this may indicate that gene amplification may not be the primary mechanism by which the HER2 protein is overexpressed in gastric cancer ${ }^{(9)}$.

In gastric cancer, the concordance between surgically resected materials and the prior biopsy specimens is high ${ }^{(14,30)}$. Our study showed a high concordance among the different analyzed specimens. When comparing the HER2 expression in biopsies, surgical specimen, lymph node and metastasis, no statistically significant difference was observed, what shows that the HER2 status can be tested using IHQ in any available sample from gastric tumor, including nodal and extranodal metastatic disease.

The TNM stage is the most important prognostic factor for gastric cancer. This classification system establishes the stage depending on the depth of invasion of gastric wall (T), the involvement of perigastric lymph nodes $(\mathrm{N})$ and the presence of distant metastasis $(\mathrm{M})^{(4)}$. The role of HER2 as a prognostic factor in gastric cancer has been controversial because some of the initial studies failed to find an association with prognosis ${ }^{(22,26)}$. Other authors, however, reported a direct correlation between HER2 expression and poorer survival ${ }^{(15,16,28,31)}$.

Yonemura et al., in their series of 260 gastric cancer, demonstrated that HER2 expression was an independent factor, and HER2 staining intensity was correlated with tumor size, serosal invasion, and lymph node metastases ${ }^{(31)}$. In a retrospective study of 108 cases, HER2 overexpression was associated with a poorer 10-year survival ${ }^{(28)}$, and in the study by Mizutani et al., a significantly poorer prognosis was observed in HER2-positive early gastric cancer in a series of 226 patients $^{(15)}$. Finally, in a Finnish study, amplification of HER2 was strongly associated with poor carcinoma-specific survival, particularly evident in the subgroup of intestinal type of cancers $(p=0.0019)^{(24)}$.

In our study, we could not establish any relation with HER2 expression and some prognostic factors such as sex, age, depth of tumor invasion and presence of metastasis $(\phi>0.05)$. Our data also showed no statistically significant difference concerning the clinical outcome $(p>0.05)$. There was only significant statistical correlation with HER2 expression and one prognostic factor, which was the $\mathrm{N}$ stage $(\phi<0.05)$.

\section{CONCLUSION}

Preclinical data have displayed significant antitumor efficacy of anti-HER2 therapies (particularly monoclonal antibodies directed towards the protein) in in vitro and in vivo models of gastric cancer. This therapy has shown to improve survival of patients with HER2-positive advanced or metastatic cancer of the stomach or GEJ.

As a result, several clinical trials are exploring, in different settings and with diverse designs, the potential of anti-HER2 therapies in gastric cancer patients, and since this novel therapeutic option is becoming the standard of care in gastric cancer, appropriate patient selection by HER2 IHC and ISH testing will now be part of routine pathology.

In our cohort of 118 Brazilian patients with gastric cancer, HER2 expression does not correlate with any histological prognostic factors or clinical outcome, with exception of the $\mathrm{N}$ stage. However, the currently available data indicate that IHQ should be used as the screening test, and in situ hybridization assays should be performed in case of equivocal (2+) results. Besides, the pathologist has an important role to ensure an accurate testing of HER2 status in these tumors.

\section{RESUMO}

Introdução: Estudos recentes indicam o papel do human epidermal growth factor receptor type 2 (HER2) no desenvolvimento de vários tipos de câncer, incluindo o gástrico. Sua superexpressão correlaciona-se com pior prognóstico e maior agressividade dessa neoplasia. Objetivos: Identificar e avaliar a expressão imuno-histoquímica de HER2 no câncer gástrico de biópsias, espécimes de ressecção cirúrgica, metástase linfonodal e metástase a distância, bem como analisar sua correlação com fatores prognósticos clínicos e histopatológicos conhecidos atualmente. Métodos: Amostras de 118 pacientes de ambos os sexos e todas as faixas etárias diagnosticados com câncer gástrico foram analisadas. A imuno-bistoquímica foi realizada utilizando o anticorpo HER2, e a sua avaliação foi feita de acordo com o protocolo do teste modificado do câncer gástrico, levando em conta a coloração basolateral ou lateral incompleta. Resultados: A expressão do HER2 não apresentou correlação com quaisquer fatores histológicos eprognósticos ou evolução clínica, com exceção do estádio $N$. Ao comparar a expressão HER2 nas biópsias de peças cirúrgicas, linfonodos e 
metástases, observou-se que 88,1\% dos espécimes apresentaram concordância. Conclusão: Como as terapias anti-HER2 estão se tornando o padrão para o tratamento do câncer gástrico, os dados atualmente disponíveis indicam que a imuno-histoquímica deve ser usada como teste de rastreamento. O patologista tem um papel importante para determinar a expressão do marcador nesses tumores. Ademais, o status do HER2 pode ser testado usando as amostras disponíveis de biópsias, peças cirúrgicas e doença metastática nodal e extranodal.

Unitermos: HER2; imuno-histoquímica; câncer gástrico; microarranjos teciduais; prognóstico.

\section{REFERENCES}

1. BANG, Y. et al. Pathological features of advanced gastric cancer (GC): relationship to human epidermal growth factor receptor 2 (HER2) positivity in the global screening programme of the ToGA trial. J Clin Oncol, v. 27, p. 15S, 2009.

2. BANG, Y. et al. Trastuzumab in combination with chemotherapy versus chemotherapy alone for treatment of HER2-positive advanced gastric or gastro-oesophageal junction cancer (ToGA): a phase 3, open-label, randomised controlled trial. Lancet, 2010.

3. BECKER K. F. et al. The use of molecular biology in diagnosis and prognosis of gastric cancer. Surg Oncol, v. 9, p. 5-11, 2000.

4. GRAVALOS, C.; JIMENO, A. HER2 in gastric cancer: a new prognostic factor and a novel therapeutic target. Ann Oncol, v. 19, n. 9, p.1523-29, 2008.

5. GRAVALOS, C. et al. Correlation between Her2/neu overexpression/ amplification and clinicopathological parameters in advanced gastric cancer patients: a prospective study. Gastrointestinal Cancers Symposium 130 (Abstr. 89), 2007.

6. HOFMANN, M. et al. Assessment of a HER2 scoring system for gastric cancer: results from a validation study. Histopathology, v. 52, p.797- 805, 2008.

7. INCA. Instituto Nacional do Câncer, Brasil. Available at: <http://www. inca.gov.br>. Accessed on: 25 nov. 2012.

8. ISHIDA, T. et al. Significance of erbB-2 gene product as a target molecule for cancer therapy. Scand J Immunol, v. 39, p. 459-66, 1994.

9. KAMEDA, T. et al. Expression of ERBB2 in human gastric carcinomas: relationship between p185ERBB2 expression and the gene amplification. Cancer Res, v. 50, p. 8002-29, 1990.

10. KELLEY, J. R.; DUGGAN, J. M. Gastric cancer epidemiology and risk factors. J Clin Epidemiol, v. 56, p. 1-9, 2003.

11. KONONEN, J. et al. Tissue microarrays for high-throughput molecular profiling of tumor specimens. Nat Med, v. 7, n. 4, p. 844-7, 1998.

12. LAUREN, P. The two histological main types of gastric carcinoma. Diffuse and so-called intestinal type carcinoma. Acta Pathol Microbiol Scand, v. 64, p. 31-49, 1965.

13. LEMOINE, N. R. et al. Amplification and overexpression of the EGF receptor and c-erbB-2 proto-oncogenes in human stomach cancer. $\mathrm{Br} J$ Cancer, v. 64, p. 79-83, 1991.

14. LORDICK, F. et al. HER2-positive advanced gastric cancer: similar HER2-positivity levels to breast cancer. Eur J Cancer, v. 5, n. 4, p. 271, 2007.
15. MIZUTANI, T. et al. Relationship of c-erbB-2 protein expression and gene amplification to invasion and metastasis in human gastric cancer. Cancer, v. 72, p. 2083-8, 1993.

16. NAKAJIMA, M. et al. The prognostic significance of amplification and overexpression of c-met and c-erbB-2 in human gastric carcinomas. Cancer, v. 85, p. 1894-2002, 1999.

17. PARK, D. I. et al. HER-2/neu amplification is an independent prognostic factor in gastric cancer. Dig Dis Sci, v. 51, p. 1371-9, 2006.

18. ROCHA, RM. et al. Construction of low cost tissue microarrays using alternative equipment for immunohistochemical study of breast tumors. J Bras Pathol Med Lab, v. 42, n. 42, p. 477-82, 2006.

19. ROSAI, J. Surgical pathology. 10. ed. USA: Elsevier, 2011. Cap. 11, p. $627-36$.

20. ROSS, J. S. et al. The HER2 receptor and breast cancer: ten years of targeted anti-HER2 therapy and personalized medicine. Oncologist, v. 14, p. 320-68, 2009.

21. SAKAI, K. et al. Expression of epidermal growth factor receptors on normal human gastric epithelia and gastric carcinomas. J Natl Cancer Inst, v. 77, p.1047-52, 1986.

22. SASANO, H. et al. Double immunostaining for c-erbB-2 and p53 in human stomach cancer cells. Hum Pathol, v. 24, p. 584-9, 1993.

23. SCHECHTER, A. L. et al. The neu oncogene: an erb-B-related gene encoding a 185,000-Mr tumour antigen. Nature, v. 312, p. 513-6, 1984.

24. TAKEHANA, T. et al. Status of c-erbB-2 in gastric adenocarcinoma: a comparative study of immunohistochemistry, fluorescence in situ hybridization and enzyme-linked immuno-sorbent assay. Int J Cancer, v. 98, n. 6, p. 833-7, 2002.

25. TANNER, M. et al. Amplification of HER-2 in gastric carcinoma: association with topoisomerase IIa gene amplification, intestinal type, poor prognosis and sensitivity to trastuzumab. Ann Oncol, v. 16, p. 273-8, 2005.

26. TATEISHI, M. et al. Clinicopathological significance of c-erbB-2 protein expression in human gastric carcinoma. Surg Oncol, v. 49, p. 209-12, 1992.

27. TOKUNAGA, A. et al. Clinical significance of epidermal growth factor (EGF), EGF receptor and c-erb-2 in human gastric cancer. Cancer, v. 75, p. 1418-25, 1995.

28. UCHINO, S. et al. Overexpression of c-erbB-2 protein in gastric cancer. Its correlation with long-term survival of patients. Cancer, v. 72, p. 317984, 1993 . 
29. WASHINGTON K. $7^{\text {th }}$ edition of the AJCC cancer staging manual: stomach.Ann Surg Oncol, v. 17, p. 3077-9, 2010.

30. YANO, T. et al. Expression of HER2 in gastric cancer: comparison between protein expression and gene amplification using a new commercial kit.J Clin Oncol, v. 22, n. 14S, 2004

31. YONEMURA, Y. et al. Evaluation of immunoreactivity for erbB-2 protein as a marker of poor short-term prognosis in gastric cancer. Cancer Res, v. 51, p. 1034-8, 1991. 